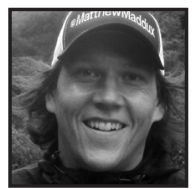

\title{
Building Bridges: Barriers to Parent Engagement Faced by Secondary Mathematics Teachers
}

\author{
Heidi L. Neufeld, Ilona I. Vashchyshyn, and Egan J. Chernoff, \\ University of Saskatchewan
}

\section{ABSTRACT}

Although parent engagement is widely supported by research, it is largely absent in the secondary mathematics classroom. Limited preservice teacher education and perceptions surrounding teacher professionalism are discussed as barriers to engaging parents. Math teachers are additionally inhibited by the antagonistic portrayal of parents in the literature and in the media, effectively alienating parents in the minds of teachers. We suggest a shift in the language used to discuss math education and the positioning of parents regarding knowledge as a way to enable parent engagement and build relationships of trust, which can transform otherwise difficult exchanges between teachers and parents.

"Don't give them a chance to ask questions"

"Never meet alone"

"Make sure you cover your [behind]"

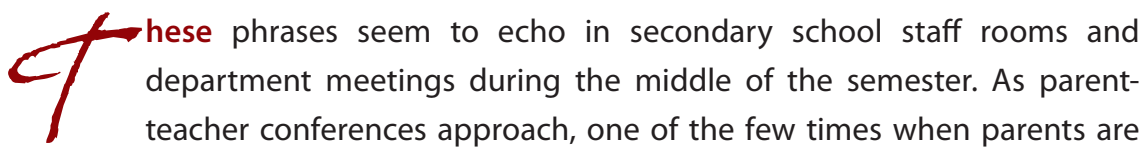
invited into secondary schools, many seasoned teachers are quick to offer advice to new teachers on how to prepare. Although many teachers may believe that there is an advantage to parents participating their child's education, it is a challenge to do so at the secondary level (Henderson \& Mapp, 2002). It can be even more difficult for secondary mathematics teachers, as they anxiously foresee the questions parents 
may pose about the new mathematics curriculum that they have been hearing so much about in the media. Unfortunately, some teachers of mathematics may enter parent conversations with their guard up, hoping it won't be broken through by parents' questions, and breathe a sigh of relief when they can again close the door and feel in control.

From the outset, we must be clear about the kinds of interactions under discussion. Often, the literature does not distinguish between parent involvement and parent engagement, and without careful investigation it is difficult to determine what precisely is meant by these terms and whether they are interchangeable (Pushor, 2007). In this article, we use the definitions proposed by Pushor (personal communication, 2016): By parent engagement, we are referring to interactions between teachers and parents that are focused on teaching and learning, whereas parent involvement refers to the volunteer activities that parents are sometimes asked to participate in. Engagement welcomes parents as decision-making partners who are valued for their own knowledge and expertise (Pushor, 2007). Parent involvement, on the other hand, assumes that parents will help the school meet its goals, rather than considering parents' own goals for the schooling of their children (Pushor, 2007). While parent engagement serves the purposes of all involved parties, involvement serves only the agenda of the school or the teacher and does not value parents' unique role (Pushor, personal communication, 2016).

A substantial body of research has already demonstrated that parent engagement can significantly contribute to student achievement (e.g., Cooper, 2016; Cox, 2005; Harris \& Goodall, 2007; Henderson \& Mapp, 2002). For instance, a meta-analysis of 80 studies concluded that, "when schools, families and community groups work together to support learning, children tend to do better in school, stay in school longer, and like school more" (Henderson \& Mapp, 2002, p. 7). Although much of the research in this area has focused on parent engagement in elementary education, continued parent engagement through middle years and high school may also have a positive effect on a student's education (Cox, 2005), including predicting the likelihood of attending college (Cooper, 2016).

Although parent engagement in general is widely supported by research, research on parent engagement in secondary mathematics education in particular is limited. While mathematics curricula have undergone significant changes in recent years, "researchers and practitioners have given relatively little attention to developing connections between schools, families, and communities as components of mathematics reform" (Sheldon \& Epstein, 2005, p. 196). In light of research 
supporting parent engagement across all subject areas, one would assume that mathematics teachers, alongside colleagues in other subjects, would be motivated to build meaningful connections between parents and schools. It seems reasonable to suppose that the stress of parent-teacher conferences, or even a difficult conversation about the reform mathematics controversy, could be alleviated if the teacher had already met the parent in question, or-better yet-had established an ongoing, mutually beneficial relationship. As we will see, multiple barriers exist that can discourage mathematics teachers from connecting with parents and can lead them to see parents as "outsiders to the school and, sometimes even, individuals to be wary or fearful of" (Pushor, 2011, p. 222). Some of these barriers, stemming from teachers' own educational experiences and the traditional positioning of teachers in schools, are common across subject areas and grade levels. However, as we will argue, the history of mathematics curriculum reform and the portrayal of parents in the literature and curricula intended to bring about mathematics education reform in both Canada and the United States, as well as the portrayal of parents in the media, may further inhibit high school mathematics teachers from engaging parents with the purpose of building a community of support for student learning.

It should also be noted that throughout this paper, the terms reform and traditional mathematics will be used. Although polarizing mathematics education pedagogy by referring to it only in terms of the extremes makes little sense (Schoenfeld, 2004), it has often been described in the media as a strict dichotomy (to be discussed). As such, while recognizing the wide spectrum of pedagogical approaches in mathematics instruction, when we refer to traditional mathematics instruction, we are referring to teaching that focuses on developing students' procedural fluency, typically centered on direct instruction and repetitive practice, which dominated pedagogical practice before constructivist theory (Piaget, 1970; Vygotsky, 1962) began to influence mathematics education research (Russell \& Chernoff, 2016). When we make reference to reform mathematics instruction, we are referring to teaching that focuses on developing conceptual understanding, typically using inquiry methods grounded in constructivist theory (Saskatchewan Ministry of Education, 2010), supported by recent curriculum renewal throughout Canada and the United States. There is a long and storied history that precedes this renewal that others have carefully addressed, and we refer the reader to these sources for more information (e.g., Russell \& Chernoff, 2016; Schoenfeld, 2004). 


\section{Limited Teacher Education in Parent Engagement}

Unfortunately, new teachers often have limited opportunities to develop a philosophy of parent engagement, to make plans for implementation in their practice, or even to consider its benefits and challenges. Their opportunities are limited because parent engagement is not often part of required curriculum for undergraduate teacher education programs, and professional development for new teachers in this regard is rare (Morris \& Taylor, 1998; Shumow \& Harris, 2000). According to Pushor (2011), it is difficult to find curriculum in Canadian teacher education programs "intended to invite teacher candidates to develop philosophical, theoretical, and practical underpinnings related to engaging parents in their children's teaching and learning" (p. 219). Consequently, "[a] lack of preparation in parental involvement strategies may lead to negative attitudes and feelings of frustrations as [...] educators are confronted with the need to involve parents in their children's education" (McBride, 1991, p. 58). As such, many teachers may enter their career without knowing how to invite a parent into a conversation about their child's education, and may even be dumbfounded when asked during a job interview how they plan to correspond with parents (McTavish, 2012). Indeed, in one survey of American teachers, new teachers identified their most frequent challenge as engaging and communicating with parents (MetLife, 2005).

Although the internship experience could be the perfect opportunity to learn firsthand about the benefits of and strategies to support parent engagement, preservice teachers may instead find themselves in a culture of fear and avoidance of parents. They may be warned, for instance, about "helicopter parents" who "are perceived to ask too many questions, to visit the school too frequently, and who want to be too big a part of the daily life which unfolds there" (Pushor, 2009, p. 141). They may hear stories about chronically negative and unreasonable parents who are to be feared-stories that are remembered and told because they are the dreaded exception, not the norm (McTavish, 2012), yet tend to color perceptions of all parents in the minds of educators (Henderson, Mapp, Johnson, \& Davies, 2007, p. 152). While teachers do report some positive experiences working with parents, their negative experiences seem to be grounded in feelings of intimidation (Hoover-Dempsey, Walker, Jones, \& Reed, 2002). In some cases, teachers do not even allow preservice teachers to be involved in parent-teacher conferences (Pushor, 2009), thus eliminating one of the only formal opportunities for a soon-to-be educator to actually meet and interact with parents. 
Despite the research that has shown possible benefits of parent engagement, the fact that teacher education programs generally do not provide meaningful learning experiences for preservice teachers in this area, coupled with a potentially negative education about the role of parents received from experienced teachers during the internship, may result in a lack of competency in making positive connections with parents in future practice. In addition, while there is some evidence that in-service teacher professional development on parent engagement does occur at the early childhood, elementary, and middle years' levels (Brown, Knoche, Edwards, \& Sheridan, 2009; McTavish, 2012; Hoover-Dempsey et al., 2002), it is much more difficult to find in secondary schools. Fear, although it may not be openly expressed as such, may underlie many teachers' interactions with parents. However, teachers may not recognize that parents are often just as wary of teachers (Stout, 2009). Without learning experiences in meaningfully engaging parents, teachers will continue to find it difficult to invite parents to participate as partners in their children's formal education.

\section{Traditional Positioning of Teachers and Parents}

Embedded in some teachers' perspectives on parents is a systemic issue that goes deeper than a lack of understanding about or fear of parent engagement. The conclusions of a 2008 study found that "a majority of teachers somewhat agreed that the most important thing for the parents of students to do was to ensure that their children make it to school every day, and then leave them alone to do their jobs" (Charleston, 2008). Preservice teachers have also observed that some practising teachers do not want "untrained" parents in their classroom, and feel a loss of authority or control when parents are involved (McBride, 1991). Embedded in these comments may be an assumption that because teachers are professionals, they hold a position of power and authority that could be undermined if engagement with parents were to become an integral part of their practice. It thus seems that many teachers either feel intimidated by parents (as discussed in the previous section) or feel superior to them, both of which likely discourage meaningful engagement with parents.

As professionals, teachers are entrusted with the responsibility of educating students under curriculum requirements, with the freedom to make instructional decisions according to their professional opinion. As is true with all professions, formal education defines and protects the authority of the professional and sets 
up boundaries that exclude "outsiders" (Sarason, 1995), and given that parents do not fit into the same professional category as teachers, by default they become the outsiders. This positioning of teachers not only distances them from parents, but also demands that they receive a certain degree of respect. Unfortunately, it seems that historically, this expectation of respect has translated into a perception of teachers as the ultimate carriers of knowledge in our society, who should not be required to answer to "outsiders" such as parents when making decisions related to practice. In short, the notion of professionalism idealizes the authority of knowledge (Grumet, 2009). For mathematics teachers, the perception of authority may be even stronger, given that mathematics is commonly viewed as a difficult subject of which only a select few are able to attain mastery. Although mathematics teachers' specialized knowledge cannot (and should not) be discounted, teachers who view themselves primarily as experts may also view parents primarily as "unknowing." As such, "parents continue to be habitually positioned in the margins of the school landscape as individuals without knowledge, or with less valued knowledge, of children, teaching, and learning" (Pushor, 2014, p. 45). Such views influence teachers' willingness and capacity to build active and mutually supportive relationships with their students' parents (McBride, 1991).

The structure and organization of secondary schools may further uphold this positioning and inhibit engagement of parents (Cooper, 2016). Although the administration may reach out to parents through newsletters or websites, such formal, one-way communication is likely to disengage parents from their child's education in the transition to high school (Davies, Tarr, \& Ryan, 2011). Frequently, the only occasion in the high school context that facilitates personal interaction are parentteacher conferences, where parents are invited into the domain of the teacher's authority and information about the student is passed down from teachers to parents, who sense the "subtle institutional barriers [that make them] feel strangely unwelcome" (Lawrence-Lightfoot, 2003, p. xviii). While in elementary school settings there may be frequent opportunities for interactions between teachers and parents, such as field trips and fundraisers, this is not often seen at the secondary level. Thus, if teachers do sense the need to build relationships with parents outside of the twice-a-year conference, this will typically be a solo endeavor, with little institutional support (Shumow \& Harris, 2000).

In the midst of teachers' positioning as authoritative professionals is the assumption that professionalism may be undermined if parents' voices were to be welcomed within the boundaries of a teacher's territory. As a teacher candidate interviewed by Pushor (2011) observed, "I think many teachers have a fear of 
letting go of their power. Perhaps they imagine if they allow parents in, the school will soon be solely in the hands of the parents" (p. 229). As is true of other professions, many teachers do not appreciate it when "outsiders" - that is, parents, "directly or indirectly, challenge their professional knowledge and practices, and sometimes the scope of their authority" (Sarason, 1995, p. 23). The belief that professional freedom is undermined by engaging parents continues to perpetuate a culture of fear and avoidance, preventing educators from reaching out and building meaningful connections with parents.

\section{Portrayal of Parents in Reform Literature}

Although many secondary school teachers may lack experience in engaging parents and may have entrenched beliefs regarding professionalism and authority, mathematics teachers face an additional barrier put forth by the portrayal of parents in the mathematics education reform literature. Peressini (1998) pointed out that in the literature published to bring reform in American mathematics education, parents were continually cast as opponents to the movement (his review of the literature is extensive, and only a few examples will be given here). Peressini considers, for instance, the National Council of Teachers of Mathematics' Recommendations (1980), which suggest that, "parents and society often mistakenly promote activities that are counterproductive to the realization of the goals they support," (p. 27), as well as the National Research Council's 1989 report Everybody Counts, which claims that "parental and legislative pressures [...] have led to many rash actions" (p. 75). After an overview of NCTM standards from 1989, 1991, and 1995, Peressini (1998) concludes: "The only instances in which parents were discussed is when they were addressed as barriers to mathematics education reform" (p. 568). In other words, these influential documents have (intentionally or unintentionally) painted parents as antagonists to the work of mathematics educators.

Within the authors' own context of Saskatchewan, parents have also been depicted as potential opponents to renewal. The front matter of the Saskatchewan mathematics curricula discusses the shift towards discovery learning, and suggests that, "for many teachers, parents, and former students this is a marked change from the way mathematics was taught to them" (Saskatchewan Ministry of Education, 2010, p. 12). Although it may be subtle, such a narrative again positions parents as "unknowing" with regard to instruction, and suggests that they will be unpleasantly surprised to hear about their child's new experiences in mathematics. 
As a Saskatchewan teacher who has spent significant time working with teachers and parents to implement new curricula, McTavish (2012) suggests that "the same assumptions made in the past about educators and parents being pitted against each other are being reiterated in the Saskatchewan curriculum documents [...] [which] does little to create a sense of partnership between parents and educators" (p. 19).

Both Peressini and McTavish recognize the negative history between parents and mathematics education reform, such as the widespread rejection of new math in the 1950s (Schoenfeld, 2004), which should not be discounted. Indeed, before teachers begin to communicate with parents on the subject of mathematics education, an awareness of the continued tension between traditionalists and reformers, which has been dubbed the "Math Wars" (Schoenfeld, 2004), would be helpful in understanding the perspectives of parents and other stakeholders. Nevertheless, despite its best efforts to inform educators about the real or perceived challenges to implementing new curricula, such literature has not only disregarded the value of parent engagement, but has also effectively alienated parents in the minds of mathematics teachers. Well before a conversation with a parent is initiated, teachers may be intentionally or unintentionally encouraged to believe that parents will be antagonistic to their (possibly unfamiliar) teaching strategies-and, consequently, that it is not worth welcoming parents as partners in the education of their children.

\section{Portrayal of Mathematics Education in the Media}

As alluded to earlier, the current state of mathematics education in both Canada and the United States has frequently been portrayed as a dichotomy of traditionalists versus reformers, with absolutely no grey area in between (Herbel-Eisenmann et al., 2016). The media has not only emphasized this dichotomy, but has also given unequal air time to the opposing parties. Consider, for example, The Great Canadian Math Debate, a 44-part series run by the Edmonton Journal that leans heavily towards the "back-to-basics" perspective (Staples, 2014), and the numerous other news articles that advocate solely for traditional approaches under the assumption that studentcentered approaches eschew knowledge of fundamental facts (e.g., Brean, 2014; Editorial, 2016). In the wave of primarily one-sided information coming from the media, teachers may assume that any parent following the news is likely being influenced by a heavily biased perspective. 
Not only does the media often fail to provide a balanced report of educated views on mathematics pedagogy, but it also continually positions parents as lobbyists for curriculum changes (Herbel-Eisenmann et al., 2016). This storyline may lead teachers to believe that all parents identify with "traditionalists," and are therefore likely to be hostile towards teachers who adopt unconventional or untraditional teaching strategies in the math classroom. Take, for instance, the March 2012 Maclean's cover story, which portrayed parents as shocked, angry, or in tears over what their children were being expected to learn in math class (Reynolds, 2012). As another example, in December 2012, CBC news' The National aired a story that featured a "new math" teacher and an "old-school" parent (Stewart, 2012). Such a story serves as a microcosm of the wider media coverage, where the roles of advocates of reform approaches, when they are given a voice, are played by teachers, while the roles of traditionalists are played by parents. Moreover, petitions lobbying for changes in mathematics curricula and instruction in British Columbia (Houle, 2013), Alberta (Tran-Davies, 2013), and Manitoba (Craigen, Stokke, \& Szechtman, 2013) were all founded (or cofounded) by parents (although a number of teachers have signed them as well). In both Alberta and Manitoba, certain petitions eventually gathered enough supporters to convince the respective provincial governments to make changes to mathematics curricula (Mertz, 2014; Martin, 2011). It may not be surprising, then, that mathematics teachers who support new curricula and corresponding changes to mathematics instruction often avoid talking to parents.

Social media may have also played a role in coloring teachers' perspectives towards parents. In the last few years, some parents have taken to websites such as Facebook to protest changes in mathematics curricula and instruction, especially those related to the American mathematics educational standards known as the Common Core. These include an engineer dad's frustrated response to his son's elementary homework assignment (The Patriot Post, 2014), a cheque from a parent to his child's elementary school written (as a derisive joke) using 10 frames instead of conventional digits (Herrmann, 2015), and many others. Such posts have been shared thousands of times and garnered as many comments, potentially increasing teachers' perception of parents as enemies to mathematics education reform. As previously discussed, the traditional positioning of teachers as professionals may widen the gap between teachers and parents by placing knowledge in the hands of teachers and positioning parents as unknowing. Such posts, however, position parents as holders of common sense, while teachers (and their "airy-fairy," "reform" pedagogy) are considered to be naïve and insensible. Both perspectives are problematic because they position teachers and parents hierarchically, rather than as common stakeholders in the education of children. 
Whether such content is shared on social media or on the evening news, it is clear that the math wars continue to draw the attention of the public and to divide parents and teachers into opposing camps. As with other popular stories, however, the response to reform mathematics curricula in Canada and in the United States has largely been sensationalized (McTavish, 2012). Certainly, there are parents who strongly oppose changes in mathematics curricula and instruction, but they do not represent all parents' perspectives. Sadly, positive stories, such as that of the parent who concluded that the Common Core is actually coherent and helpful to her child's learning in mathematics (Sharps, 2014), are rare in the media, which has tended to perpetuate a dualistic portrayal of mathematics education. This suggests to viewers that there are only two ways to teach mathematics, and further, that all parents believe that the traditional approach is far superior, effectively pitting teachers and parents against one another. This may discourage teachers from envisioning parents as open to productive conversations about multiple perspectives on the teaching and learning mathematics, and as such, adds another barrier between the two parties.

\section{Discussion: Engagement Requires Relationship}

As we have argued, a limited focus in teacher education, the traditional positioning of teachers as authority figures, the portrayal of parents in the mathematics education literature, and the positioning of parents in the media all have the potential to situate parents as opponents in the minds of teachers. These realities can act as barriers for teachers, perhaps mathematics teachers in particular, to reach out to parents. However, we suggest that shifting the way we talk about mathematics education and the way in which we view parents can transform our interactions. Ultimately, even difficult exchanges between parents and teachers can be made easier when the parties are in relationship, which requires teachers to make meaningful, ongoing connections with parents.

No matter where one may fall on the spectrum of "traditional" to "reform" pedagogy, a better position from which to initiate conversations with parents, and perhaps even influence the wider discourse, stems from reframing our conversation in terms of a spectrum, rather than a dichotomy, and reminding ourselves and others that despite the storyline perpetuated by the media, there are more than two ways to teach mathematics (Herbel-Eisenmann et. al., 2016). This shift opens up space for teachers to articulate their personal philosophy of mathematics education that underlies their instructional decision making. When teachers are 
open to talking about the space between the extremes of traditional and reform, it also opens up space for parents to voice their concerns, some of which may stem from misconceptions (such as the misconception that math teachers no longer believe students should memorize multiplication tables) that can be addressed with the goal of mutual understanding, rather than simply dismissed as naïve. Such a change in our language allows for the possibility of identifying common goals not only between so-called reformers and traditionalists, but also between teachers and parents (McGarvey \& McFeetors, 2015). As Lawrence-Lightfoot writes (2003), "When parents and teachers begin to trust each other and recognize the mutuality of their concern for the child [...] it is like 'close neighbors chatting over the back fence'"' (p. 71).

Another important shift that should take place in order to support parent engagement is a change in how parents are positioned with respect to their knowledge. Although teachers may be experts in pedagogy and curriculum, parents are experts with regard to their children, and as such, have a wealth of knowledge that can complement the teacher's knowledge and support their children's learning of mathematics (Peressini, 1998; Pushor, 2010). When students enter a mathematics classroom, they bring along their past experiences, attitudes, and perceptions of the subject. Parents, because of their unique care-giving role, have access to this knowledge in a way that the teacher does not (Pushor, personal communication, 2016). As a first step, teachers might consider asking: "What has been your child's journey with mathematics?" and incorporating this knowledge into their work with that student in the classroom. Obviously, the constraints on teachers' time make it unreasonable to expect secondary teachers to build strong relationships with every parent, but it is reasonable for teachers to initiate conversations by sending out the first email, and following up in cases where they foresee it as being particularly beneficial. Perhaps the key to the teacher-parent relationship, however, besides communication, is a genuine willingness to listen to the other's perspective and to learn something new (Lawrence-Lightfoot, 2003). Such mutually beneficial relationships, where meaningful knowledge is shared from both sides, cannot be established during a once-a-semester conversation (Henderson et al., 2007).

With relationship comes the opportunity for transparency. This notion may strike fear into teachers who may be concerned that their authority will be undermined in becoming more accountable to parents. Often, parents only see or hear about small snapshots of the classroom from their children, which may not give justice to a teacher's work. In fact, Noddings (2009) suggests that rather than framing 
communication with parents as accountability, which suggests being forced to answer up the chain of power, it should be viewed as a responsibility, which "asks us to respond to the legitimate needs of those placed in our care" (p. 17). As parents are given the opportunity to see a more holistic picture of their child's classroom, trust can be built. Then, as teachers and parents grow in their relationships with one another, a foundation is built for meaningful collaboration and mutual accountability (Warren, Hong, Rubin, \& Uy, 2009).

Through transparency, parents are given the opportunity to see the scope of teachers' work beyond a once-a-semester, five-minute interaction. What if we shared with parents not only exam results and report card comments, but also discussed our classroom culture, expectations and policies, common types of activities, and our ways of being and doing? Whether this conversation takes place in person or through a letter or an email, by allowing parents to see more than just a snapshot of our work, we accept the reality that parents, as caregivers, are crucial stakeholders in their children's learning journey (Noddings, 2009). Finally, transparency encourages knowing, rather than assuming. Rather than assuming that a parent will be antagonistic towards their approach to teaching mathematics, teachers have the opportunity to recognize the value that parents see in mathematics education. Conversely, rather than assuming that a teacher does not care about a struggling student, parents are able to recognize that the teacher chooses methods and strategies with the best interests of his or her students in mind. Countering the negative stereotypes perpetuated about parents also requires teachers to be willing to question what shapes their opinions of parents, and whether the stories they themselves pass on are productive or destructive.

\section{Conclusion}

For all teachers, engaging parents is a challenging but rewarding endeavor, and for teachers of mathematics, the stakes are particularly high. History has shown us that failure to engage with parents in mathematics education has, in some cases, led to ineffective implementation of pedagogical change (Peressini, 1998; Schoenfeld, 2004). Indeed, our efforts to influence the landscape of the teaching and learning of mathematics may be in vain if we do not consider how we can work collaboratively with parents, rather than against them. Only teachers who choose to reach past the barriers and actively engage parents will see the positive effect that relationships with parents could have on their teaching, on their students' learning, 
and on what might otherwise have been difficult conversations. An approach based in relationship - which values parents' participation from the position of their own interests rather than those imposed by the school or teacher (Warren et al., 2009) this is an approach truly in the spirit of parent engagement.

\section{References}

Brean, J. (2014, August 21). Math wars: Rote memorization plays crucial role in teaching students how to solve complex calculations, study says. National Post. Retrieved from http://news.nationalpost.com/news/can $\mathrm{ada} /$ math-wars-rote-memorization-playscrucial-role-in-teaching-students-how-tosolve-complex-calculations-study-says

Brown, J. R., Knoche, L. L., Edwards, C. P., \& Sheridan, S. M. (2009). Professional development to support parent engagement: A case study of early childhood practitioners. Early Education \& Development, 20(3), 482-506.

Charleston, C. R. (2008). Perspectives of teachers and parents regarding parent participation in education (Doctoral dissertation). Retrieved from ProQuest Dissertations \& Theses Global; ProQuest Education Journals (250147510).

Cooper, C. R. (2016). Staying on the path toward college interactive case: Piecing it all together. Retrieved from http:// www.hfrp.org/publications-resources/ browse-our-publications/staying-on-thepath-toward-college-interactive-casepiecing-it-all-together

Cox, D. D. (2005). Evidence-based interventions using home-school collaboration. School Psychology Quarterly, 20(4), 473-497.

Craigen, R., Stokke, A., \& Szechtman, F. (2013). Western initiative for strengthening education in math [petition]. Retrieved from https://wisemath.org/

Davies, J. D., Tarr, J., \& Ryan, J. (2011). What we tell them is not what they hear: The importance of appropriate and effective communication to sustain parental engagement at transition points. International Journal About Parents in Education, 5(2), 25-34.
Editorial. (2016, December 9). Editorial: Strong math skills are vital for our students. Calgary Herald. Retrieved from http:// calgaryherald.com/opinion/editorials/ editorial-math-skills-are-vital

Grumet, M. (2009). Commentary: The politics of curriculum creativity. LEARNing Landscapes, 2(2), 25-30.

Harris, A., \& Goodall, J. (2007). Engaging parents in raising achievement: Do parents know they matter? Department for Children, Schools, and Families, University of Warwick. Retrieved from http://library.bsl.org.au/ jspui/bitstream/1/3469/1/Engaging $\% 20$ parents $\% 20$ and $\% 20$ raising $\% 20$ achieve ment_Alma\%20Harris_2007\%20.pdf

Henderson, A. T., \& Mapp, K. L. (2002). A new wave of evidence: The impact of school, family, and community connections on student achievement. Austin, TX: Southwest Educational Development Laboratory. (National Centre for Family \& Community Connections with Schools). Retrieved from https://www.sedl. org/connections/resources/evidence.pdf

Henderson, A. T., Mapp, K. L., Johnson, V. R., \& Davies, D. (2007). Beyond the bake sale: The essential guide to family-school partnerships. New York: The New Press.

Herbel-Eisenmann, B., Pape, S. J., Sinclair, N., Stephan, M., Chval, K. B., Wanko, J. J., et al. (2016). Positioning mathematics education researchers to influence storylines. Journal for Research in Mathematics Education, 47(2), 102-117.

Herrmann, D. (2015, September 16). Wrote a check to Melridge Elementary using common core numbers. Retrieved from https://www.facebook.com/photo.php?fbid $=10208079501134099 \&$ set $=a .232023033400$ 1.2140526.1496845642\&type $=3$ 
Hoover-Dempsey, K. V., Walker, J. M., Jones, K. P., \& Reed, R. P. (2002). Teachers involving parents (TIP): Results of an in-service teacher education program for enhancing parental involvement. Teaching and Teacher Education, 18(2002), 843-867.

Houle, T. (2013). Mastering the basics of mathematics in BC schools [petition]. Retrieved from https://www.gopetition.com/petitions /mastering-the-basics-of-mathematics-inbc-schools.html\#

Lawrence-Lightfoot, S. (2003). The essential conversation: What parents and teachers can learn from each other. New York: Ballantine Books.

Martin, N. (2011, September 10). Teachers' math skills 'alarmingly weak.' Winnipeg Free Press. Retrieved from http://www.winnipeg freepress.com/local/teachers-math-skillsalarmingly-weak-129577963.html

McBride, B. A. (1991). Preservice teachers' attitude toward parental involvement. Teacher Quarterly, 18(4), 57-67.

McGarvey, L.M., \& McFeetors, P.J. (2015). Reframing perceptions of arithmetic learning: A Canadian perspective. In X. Sun, B. Kaur \& J. Novotná (Eds.) Proceedings of the twenty-third International Commission on Mathematical Instruction: Primary mathematics study on whole numbers (pp. 113-123). Macau, China: ICMI.

McTavish, C. (2012). A narrative inquiry into parent engagement in the mathematics curriculum (Unpublished master's thesis). University of Saskatchewan, Saskatoon, Canada.

Mertz, E. (2014, June 23). Following pushback, Alberta education will change math curriculum. Global News. Retrieved from http://globalnews.ca/news/1411219/ following-pushback-alberta-education -will-change-math-curriculum/

MetLife, Inc. (2005). The MetLife survey of the American teacher, 2004-2005: Transitions and the role of supportive relationships. Retrieved from https://www.metlife.com/ metlife-foundation/about/survey-american -teacher.html
Morris, V. G., \& Taylor, S. I. (1998). Alleviating barriers to family involvement in education: The role of teacher education. Teacher and Teacher Education 14(2), 219-231.

National Council of Teachers of Mathematics. (1980). An agenda for action: Recommendations for school mathematics of the 1980s. Retrieved from http://www.nctm. org/flipbooks/standards/agendaforaction/ index.html

National Research Council. (1989). Everybody counts: A report to the nation on the future of mathematics education. Washington, DC: National Academy Press. Retrieved from http://www.nap.edu/read/1199/chapter/1

Noddings, N. (2009). Commentary: Responsibility. LEARNing Landscapes, 2(2), 17-23.

Peressini, D. (1998). The portrayal of parents in the school mathematics reform literature: Locating the context for parental involvement. Journal for Research in Mathematics Education, 29(5), 555-582.

Piaget, J. (1970). The science of education and the psychology of the child. New York: Grossman.

Pushor, D. (2007). Parent engagement: Creating a shared world. Toronto, CA: Ontario Ministry of Education. Retrieved from http://www. ebrary.com

Pushor, D. (2009). The situation of parents in the curricular commonplaces: A place of equal rank? LEARNing Landscapes, 2(2), 139-153.

Pushor, D. (2010). "Parent engagement in mathematics is just not possible." Or is it? Vinculum, 2(1) 20-32.

Pushor, D. (2011). Attending to milieu: Living a curriculum of parents alongside teacher candidates. In J. Kitchen, D. Ciuffetelli Parker, \& D. Pushor (Eds.), Narrative inquiries into curriculum making in teacher education (pp. 217-238). Bingley, UK: Emerald Group Publishing Limited.

Pushor, D. (2014). Teachers' narrative understandings of parents: Living and reliving "possible lives" as professionals. Journal of Family Diversity in Education, 1(1), 40-57. 
Reynolds, C. (2012, March 13). Have you finished your homework, mom? Maclean's, 125(10), 44-47. Retrieved from http://www.macleans.ca/society/life/ have-you-finished-your-homework-mom/

Russell, G. L. \& Chernoff, E. J. (2016). The transreform approach to the teaching and learning of mathematics: Re-viewing the math wars. Far East Journal of Mathematical Education, 16(1), 69-109.

Sarason, S. B. (1995). Parental involvement and the political principle. San Francisco: Jossey-Bass Publishers.

Saskatchewan Ministry of Education. (2010). 2010 Saskatchewan curriculum: Foundations of mathematics and pre-calculus 10. Retrieved from https://www.curriculum.gov.sk.ca/web apps/moe-curriculum-BBLEARN/index. jsp?lang=en\&subj=mathematics\&level= foundations10

Schoenfeld, A. H. (2004). The math wars. Educational Policy, 18(1), 253-286.

Sharps, L. (2014, October 21). Everything you hate about your kid's 'new math' may be wrong [web log post]. Retrieved from http:// thestir.cafemom.com/big_kid/178439/ new_math_common_core_kids

Sheldon, S. B., \& Epstein, J. L. (2005). Involvement counts: Family and community partnerships and mathematics achievement. The Journal of Educational Research, 98(4), 196-206.
Shumow, L., \& Harris, W. (2000). Teachers' thinking about home-school relations in low income urban communities. The School Community Journal, 10(1), 9-23.

Staples, D. (2014). The great Canadian math debate [series]. Edmonton Journal. Retrieved from http://edmontonjournal.com/tag/thegreat-canadian-math-debate

Stewart, B. (2012, December 2). Problems with new math. The National. Retrieved from http://www.cbc.ca/player/play/2312097941

Stout, A. C. (2009). Comparing rural parent and teacher perspectives of parental involvement: A mixed methods study. (Unpublished doctoral study). Walden University, Minneapolis, MN.

The Patriot Post. (2014, March 21). Common Core baffles father. Message posted to https:// www.facebook.com/PatriotPost/photos/a.8 2108390913.80726.51560645913/101521430 72400914/?type $=1 \&$ stream_ref $=10$

Tran-Davies, N. (2013). Back to basics: Mastering the fundamentals of mathematics [petition]. Retrieved from https://www.change.org/p/ back-to-basics-mastering-the-fundamen tals-of-mathematics

Vygotsky, L. S. (1962). Thought and language. Cambridge, MA: MIT Press.

Warren, M. R., Hong, S. Rubin, C. L., \& Uy, P. S. (2009). Beyond the bake sale: A community based relational approach to parent engagement in schools. Teachers College Record, 11(9), 2209-2254.

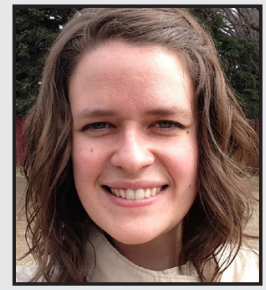

Heidi L. Neufeld is a recent Bachelor of Education graduate from the University of Saskatchewan. As a secondary mathematics teacher early in her career, Heidi's present research interest is in the field of parent engagement, specifically as it interacts with the current context of mathematics education in Canada. She holds a position as a director of the Saskatchewan Mathematics Teachers Society (SMTS) and loves to collaborate with other mathematics teachers in person and via Twitter. 


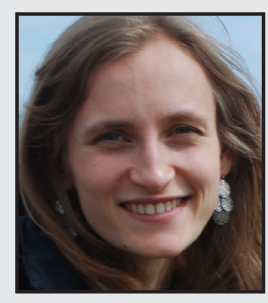

llona I. Vashchyshyn is a high school mathematics teacher in Saskatchewan interested in facilitating meaningful problem solving and posing in a collaborative math classroom. She holds Bachelor's degrees in Secondary Education and Mathematics, both from the University of Saskatchewan. Currently, Ilona is the Vice-President of the Saskatchewan Mathematics Teachers Society and editor of its periodical, The Variable. Through this role, she hopes to facilitate communication and collaboration between mathematics educators in the province (and beyond).

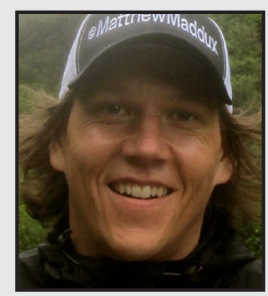

Egan J. Chernoff is an Associate Professor of Mathematics Education in the College of Education, University of Saskatchewan. Currently, Egan is the English/Mathematics editor of the Canadian Journal of Science, Mathematics and Technology Education and an associate editor of the Statistics Education Research Journal. His research utilizes logical fallacies and particular theories, models, and frameworks from the fields of mathematics education and cognitive psychology to account for prospective elementary, middle, and high school math teachers' normatively incorrect, inconsistent and sometimes inexplicable responses to a variety of probabilistic tasks. He is also an ardent user of social media for mathematics education. 